This is an author produced version of a paper published in International Journal of Forest Engineering.

This paper has been peer-reviewed and is proof-corrected, but does not include the journal pagination.

Citation for the published paper:

Back Tomas Ersson, Linus Jundén, Erik Mattias Lindh, and Urban Bergsten. (2014) Simulated productivity of conceptual, multi-headedtree planting devices. International Journal of Forest Engineering. Volume: 25, Number: 3, pp 201-213.

http://dx.doi.org/10.1080/14942119.2014.972677.

Access to the published version may require journal subscription. Published with permission from: Taylor \& Francis.

Epsilon Open Archive http://epsilon.slu.se 


\title{
Simulated productivity of conceptual, multi-headed tree planting devices
}

\author{
Back Tomas Ersson ${ }^{\mathrm{a}}$, Linus Jundén ${ }^{\mathrm{b}}$, Erik Mattias Lindh ${ }^{\mathrm{b}}$ and Urban Bergsten ${ }^{\mathrm{a}}$ \\ ${ }^{a}$ Department of Forest Biomaterials and Technology, SLU, Umeå, Sweden; \\ ${ }^{b}$ UMIT Research Lab, Umeå University, Sweden
}

\begin{abstract}
Corresponding author: Back Tomas Ersson, Department of Forest Biomaterials and Technology, SLU, SE-90183 Umeå, Sweden. Email: back.tomas.ersson@slu.se
\end{abstract}

\begin{abstract}
Mechanized tree planting is presently enjoying a revival in Fennoscandia with increased focus on further technical development. To explore the productivity effect of multiple heads on crane-mounted tree planting devices, we used a discrete-event simulation tool in which excavator-mounted one- to four-headed devices reforested clearcuts with variable frequencies of obstacles. During the simulations, the device models either mounded or inverted soil and then planted seedlings. A planting head could be hindered by stones and roots from performing these tasks, thus causing queuing delays for multi-headed devices. Surface boulders, stumps, and humus layers also slowed down the work. The results showed that productivity increased significantly with increasing numbers of planting heads on terrain with sparse or moderate obstacles, regardless of using faster or slower soil preparation methods or seedling reloading systems. However, on obstacle-rich terrain, three-headed planting devices were more productive than four-headed, while oneheaded were as equally productive as two-headed devices. Obstacle-rich terrain sometimes inhibited those large four-headed devices from planting even one seedling at a given machine stationary point. Therefore, we conclude that three planting heads per cranemounted device seems to be the most realistic configuration for combining high productivity with good silvicultural results on all the terrain types that a planting machine might work on in Fennoscandia. Future studies should investigate the silvicultural effects of different tree spacing geometries and the corresponding suitable geometrical design of three-headed crane-mounted planting devices.
\end{abstract}

Keywords: tree planting machine; mechanized planting; planting head; discrete-event simulation; terrain model; inverting; mounding; site preparation; scarification; silviculture 


\section{Introduction}

In Fennoscandia, forest owners are legally obliged to reforest stands after clearcutting. Planting tree seedlings is the preferred method of stand regeneration in both Sweden and Finland (Eriksson 2013; Juntunen \& Herrala-Ylinen 2013). Even so, successful reforestation with tree planting is dependent on the work quality of both the site preparation and planting task (Luoranen et al. 2011). The work quality of both these tasks can influence seedling survival (e.g. Huuri 1972; Hallonborg et al. 1995; Nieuwenhuis \& Egan 2002) and growth (e.g. Örlander et al. 1991; Saksa et al. 2005).

Today's tree planting machines, which use boom-tip planting devices to simultaneously scarify the soil and plant seedlings, plant seedlings with equally good (Härkönen 2008) or better (Luoranen et al. 2011) work quality than operational manual planting in Finland. Similarly, clearcuts in southern Sweden reforested with excavator-mounted Bracke Planters have over the last five years shown better work quality during same-year (Ersson \& Petersson 2013a) and three-year follow-ups (Ersson \& Petersson 2013b) compared to the vastly more common combination of disc trenching and manual tree planting. Mounding as soil preparation method, deep-planting of seedlings (planting with up to one-half stem buried; Örlander et al. 1991), and better educated machine operators are three of the main reasons for better quality planting with the Bracke Planter in southern Sweden.

Stand regeneration with the Bracke Planter is, nevertheless, up to $25 \%$ costlier than the combination disc trenching and manual tree planting in southern Sweden (Ersson 2010). In Finland, using either the one-headed Bracke Planter or the two-headed M-Planter, mechanized tree planting also tends to be more than $20 \%$ costlier than the typical combination mounding and manual tree planting (Hallongren et al. 2014). Most of these higher costs can be attributed to the planting machines' low productivities (Ersson et al. 2014). Therefore, improving the productivity of planting machines is of general interest for forest owners.

Initial research and development of tree planting machines for moraine soils focused on continuously advancing planting machines (Bäckström 1978; Hallonborg 1997). In the early 1990s, however, boom-tip planting devices were developed and had completely superseded continuously advancing planting machines within a decade (Ersson 2010). Lower costs (Åhlund 1995) and higher work quality with boom-tip planting devices (Hallonborg et al. 1997) were the 
main reasons for this shift in planting machine design. The one-headed Bracke Planter was the first boom-tip planting device invented (von Hofsten 1993). But because the base machines carrying the planting devices tend to have the capacity to handle yet heavier devices (Hallonborg et al. 1997), two-headed planting devices were soon invented, the first being the EcoPlanter (Mattson 1997). However, the EcoPlanter produced inferior quality planting results in some trials (Saarinen 2006; Luoranen et al. 2011) and is today not on the market.

Still, the EcoPlanter had exemplified well the productivity advantage of two-headed planting devices, so in 2006, the M-Planter was introduced (Rantala et al. 2009). The two-headed M-Planter attaches to an excavator's crane; mounds and then deep-plants seedlings; and has reached productivities exceeding 300 seedlings per productive work hour (pl/PWh, excluding delays) during time studies on clearcuts where stump and slash had been harvested (Laine \& Rantala 2013). Ersson et al. (2013) reported a theoretical productivity over $400 \mathrm{pl} / \mathrm{PWh}$ when the M-Planter was simulated on obstacle-sparse terrain, and this figure was about $60 \%$ higher than that of the one-headed Bracke Planter. Nonetheless, follow-ups of practical work with the MPlanter have noted average productivity figures only half as high as the theoretical ones (Rantala \& Laine 2010).

One reason why the M-Planter's average follow-up productivity has been so low (150$200 \mathrm{pl} / \mathrm{PWh}$ ) may be due to its large size. The M-Planter is circa $2.5 \mathrm{~m}$ wide and has $2 \mathrm{~m}$ between planting dibbles. In general, planting machine operators can be assumed to choose cohesive microsites and avoid those that require the planting device to straddle obstacles. Thus, planting devices with as narrow dibble distance as possible should be more productive, especially on obstacle-rich terrain. In practical forestry, how narrow the dibble distance may be depends on the forest owner's silvicultural prescriptions, which stipulate the minimum seedling spacing. Among Sweden's largest forest owners, the minimum seedling spacing varies from 0.6 m (Normark 2011) to 1.5 m (Åke Granqvist, Bergvik Skog, pers. comm. 2014; unreferenced), with the shorter distance adhering to the minimum seedling spacing stipulated in the Swedish Forestry Act (Skogsstyrelsen 2014) and the longer distance aspiring to promote even seedlingdispersal over the clearcut. Research on minimum seedling spacing of conifers in the Nordic countries has mainly focused on measuring the effect of rectangular spacing (Lindman et al. 1985; Salminen \& Varmola 1993; Davidsson 2002). 
The method of soil preparation also affects the planting machines' productivity. For example, patch scarification, the simplest soil preparation method, can be performed twice as quickly compared to mounding when using Karl-Oskar, a boom-tip scarifying device (Sundblad 2009). Similarly, inverting (also termed inverse scarification) takes circa $33 \%$ longer to perform with the Karl-Oskar device than mounding. Inverting is a soil preparation method which improves the survival of seedlings planted on mesic sites in boreal forests (Granhus et al. 2003; Hallsby \& Örlander 2004; Johansson et al. 2013), although slightly lower seedling performance with inverting compared to mounding has been noted on frost-heave susceptible soils (Heiskanen et al. 2013). When inverting using Karl-Oskar, the operator first makes a mound then pushes the mound back into the scoop/pit. Since the mounds are always in contact with the ground, we could call this the on-ground inverting method. In contrast, we could term the method in which an excavator bucket is used to dig up a mound and then lay it back upside-down into the scoop (Saksa et al. 2002; Löf et al. 2012) as bucket inverting. Nevertheless, because they prepare two or more planting spots simultaneously, multi-headed planting devices would in theory suffer relatively less from productivity losses compared to one-headed devices when using timeconsuming scarification methods.

Principally, the more planting heads per tree planting device, the higher the productivity is, at least on obstacle-free terrain. However, most Fennoscandian forest terrain is not obstaclefree. Typical forest/clearcut terrain in southern Sweden, for example, comprises moraine soil with stumps, roots (Ersson et al. 2013), surface boulders (Stendahl et al. 2009) and overlying humus layers (also called O-horizon; Olsson et al. 2009). Therefore, for novel planting devices to be realistic, they must also perform satisfactorily on clearcuts with obstacles. For this purpose, we chose to use discrete-event simulations, a method that has been used successfully for product development in forest operations many times previously (Sjunnesson 1970; Andersson et al. 1977; Asikainen 1995; Talbot \& Suadicani 2005; Sängstuvall et al. 2012; Jundén et al. 2013).

The objective of this study was to compare the simulated productivities of feasible, cranemounted, multi-headed planting devices on Nordic clearcut terrain with today's commercially available one- and two-headed varieties. Since mechanized tree planting entails much time spent preparing soil and handling seedlings, our secondary aim was to investigate how less time spent on seedling handling (faster seedling reloading) and longer time spent on soil preparation (inverting) influence the comparisons. 


\section{Materials and methods}

In essence, this study used the models and discrete-event simulation tool described mainly in Ersson et al. (2013) but also in Jundén (2011). Explained below are the additions and improvements made to the models for this specific study, and its experimental design.

\section{Terrain models}

The terrain models used the stump, root plate, and root models outlined in Ersson et al. (2013). This meant that the stumps were spatially allocated according to the stems in Herlitz's (1975) type stands numbered 452,553 , and 554, with roots spreading from the root plate based on a random azimuth. However, because we added humus layers to the terrain in this study, we assumed the main lateral roots to be non-visible obstacles.

Stones were distributed randomly and could be either non-visible underground obstacles or visible surface boulders. Surface boulders hindered the choosing microsite task while underground stones (depending on their size) potentially hampered the mounding and planting tasks. Underground stones were modelled as in Ersson et al. (2013) except that stone frequency and mean stone volume were reverted to Andersson et al.'s (1977) original proportions. We made this reversal because the presence of surface boulders now made our terrain similar to the clearcuts sampled by Larsson (1976).

Surface boulders were modelled as spherical, visible obstacles with the midpoints placed on the mineral soil's surface. Boulders were randomly allocated over the type stand but could not overlap a stump, root plate, or another surface boulder. The boulders' diameter distribution was sourced from Figure 1. Because of the overlap prohibition and that we allocated surface boulders after the stumps, all boulders $>40 \mathrm{dm}$ in diameter were changed to $40 \mathrm{dm}$ during the simulations. The surface boulder frequency per ha was linked to the terrain models' boulder quotas according to the correlations presented by Stendahl et al. (2009, Figure 2, in which the intra-data-point variation is normally distributed; Johan Stendahl, SLU, pers. comm. 2012; unreferenced). 


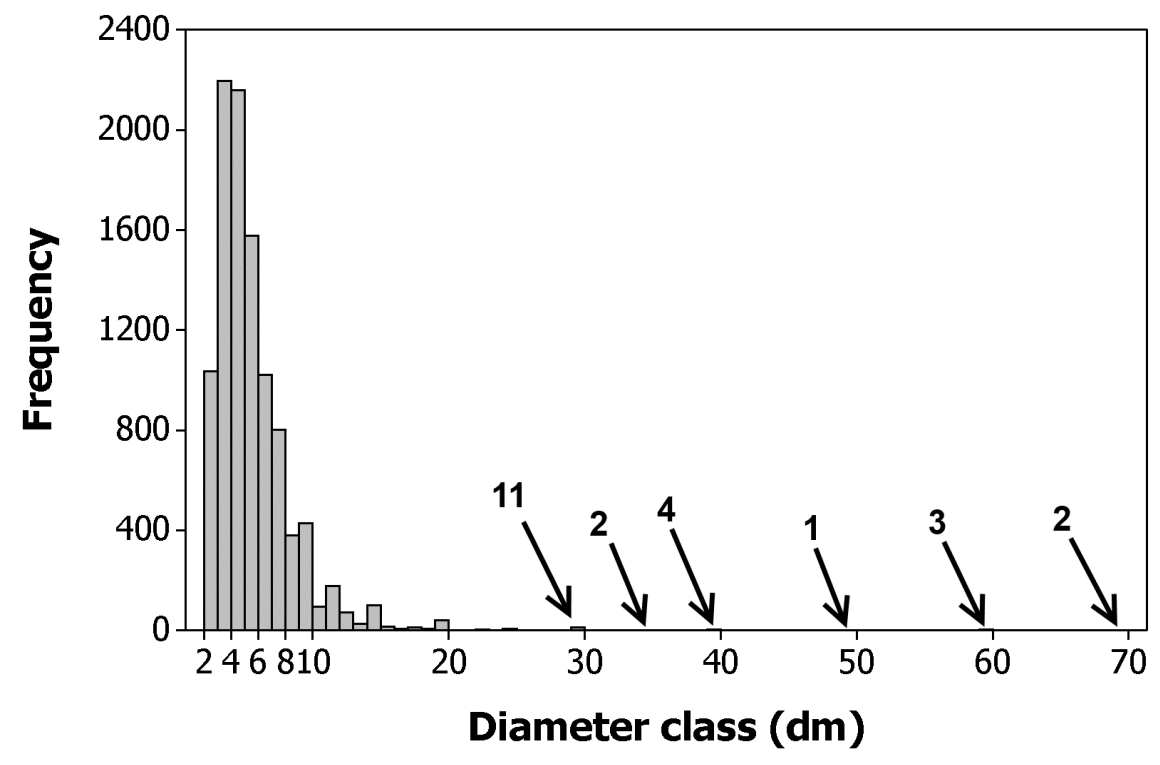

Figure 1. The diameter class distribution of surface boulders $>2 \mathrm{dm}$ on moraine soils as measured on 1019 variably sized sample plots during the second Swedish National Forest Soil Inventory 1993-2001 (Ståndortskarteringen 2014). Minimum value: $2 \mathrm{dm}$; maximum value: $69 \mathrm{dm} . \mathrm{n}=10187$. Data labels and arrows are provided for diameter classes $>25 \mathrm{dm}$ that contain at least one boulder.

Since the presence of humus layers affects the productivity of boom-tip planting devices (Sønsteby \& Kohmann 2003; St-Amour 2009; Rantala \& Laine 2010), LFH layers (organic horizons, hereafter collectively termed humus) were added to our terrain models to make them more realistic. These layers of biotic material cover the soil; consequently, they lessened the chance of striking underground stones when digging and made all roots become non-visible obstacles in our simulations. However, the humus layers were positioned underneath the stumps so that the roots grew in the humus and not only in the soil. As according to Ståndortskarteringen's (2014) definition, surface boulders were still visible obstacles even when covered by humus layers. Based on the categorization of Berg (1982), we modelled three classes of humus thickness as follows: thin (triangular distribution: $0-5 \mathrm{~cm}$; mode at $1 \mathrm{~cm}$ ), moderately thick (triangular distribution: $5-15 \mathrm{~cm}$; mode at $10 \mathrm{~cm}$ ), thick (triangular distribution: $15-30 \mathrm{~cm}$; mode at $22 \mathrm{~cm}$ ). In each terrain model, a certain humus thickness class was applied and a grid of $1 \mathrm{~m}$ spacing was laid out. Then, a value was randomly drawn from the relevant triangular distribution and allocated to each node (Figure 2). Thicknesses between a pair of nodes were interpolated with cubical splines. 


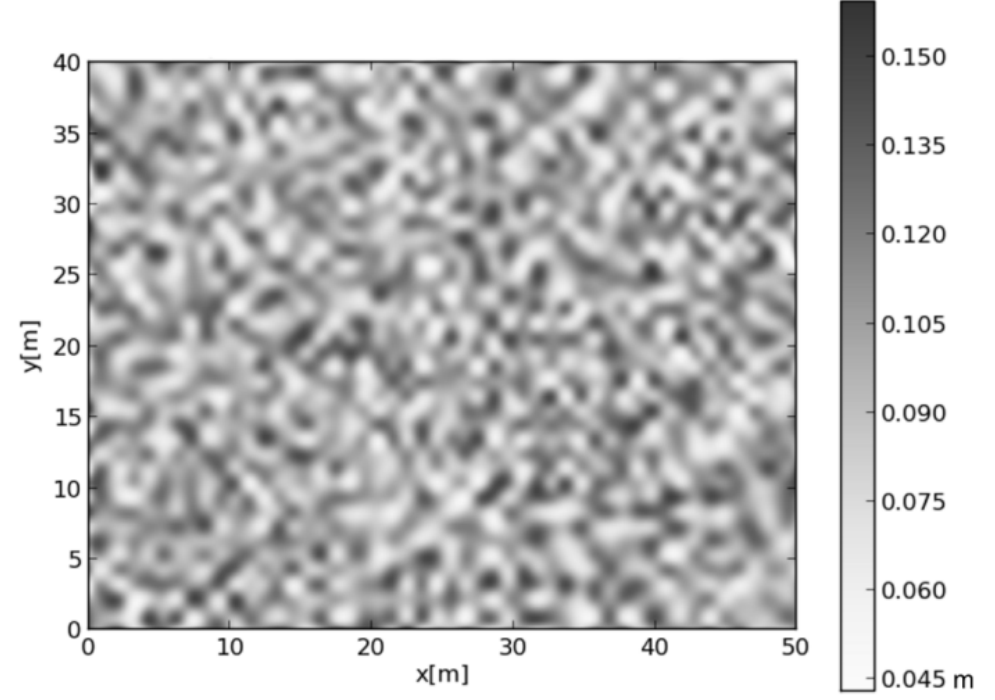

Figure 2. Screen snapshot of the humus depth on terrain model 3 (moderately thick humus). The humus depth varies from $5 \mathrm{~cm}$ (light shade) to $15 \mathrm{~cm}$ (dark shade).

Table 1 presents our five terrain models; terrain model 2 contained the fewest number of potential obstacles whereas terrain model 4 the most. Terrain model 3 was chosen to represent typical southern Swedish clearcuts.

Table 1. The terrain models' descriptive parameters.

\begin{tabular}{|c|c|c|c|c|c|c|c|c|}
\hline $\begin{array}{l}\text { Terrain } \\
\text { model }\end{array}$ & Description & $\begin{array}{l}\text { Stumps } \\
\text { per ha }\end{array}$ & $\begin{array}{c}\text { Stump } \\
\text { basal } \\
\text { area } \\
\left(\mathrm{m}^{2} / \mathrm{ha}\right)\end{array}$ & $\begin{array}{c}\text { Boulder } \\
\text { quota }{ }^{\text {a) }} \\
(\%)\end{array}$ & $\begin{array}{l}\text { Stone } \\
\text { frequency } \\
\left(\mathrm{n} / \mathrm{m}^{2}\right)\end{array}$ & $\begin{array}{c}\text { Mean } \\
\text { stone } \\
\text { volume } \\
\left(\mathrm{dm}^{3}\right)\end{array}$ & $\begin{array}{c}\text { Surface } \\
\text { boulders } \\
(\mathrm{n} / \mathrm{ha})\end{array}$ & $\begin{array}{l}\text { Modal } \\
\text { humus } \\
\text { thickness } \\
(\mathrm{cm})\end{array}$ \\
\hline 1 & $\begin{array}{l}\text { Few large stumps, } \\
\text { few stones, thin } \\
\text { humus }\end{array}$ & 230 & 71.5 & 25 & 28 & 0.9 & 0 & 1 \\
\hline 2 & $\begin{array}{l}\text { Few large stumps, } \\
\text { few stones, thick } \\
\text { humus }\end{array}$ & 230 & 71.5 & 25 & 28 & 0.9 & 0 & 22 \\
\hline 3 & $\begin{array}{l}\text { Many small } \\
\text { stumps, moderate } \\
\text { stones, } \\
\text { moderately thick } \\
\text { humus }\end{array}$ & 730 & 49.9 & 55 & 43 & 1.5 & 1800 & 10 \\
\hline 4 & $\begin{array}{l}\text { Many large } \\
\text { stumps, many } \\
\text { large stones, thin } \\
\text { humus }\end{array}$ & 635 & 95.5 & 75 & 23 & 4.3 & 4000 & 1 \\
\hline 5 & $\begin{array}{l}\text { Many large } \\
\text { stumps, many } \\
\text { large stones, thick } \\
\text { humus }\end{array}$ & 635 & 95.5 & 75 & 23 & 4.3 & 4000 & 22 \\
\hline
\end{tabular}

a) See Berg (1982) for definition. Also termed stoniness or rockiness. 


\section{Planting device models}

The planting devices were attached to the one-armed machine models described in Ersson et al (2013). Being a model of an intermittently advancing planting machine, the simulated base machine stood still at stationary points while working with the crane in a semicircle (Figure 3). At each stationary point, the planting machine model performed the following four main tasks cyclically: moving crane, choosing microsite, mounding, and planting. The secondary tasks, moving base machine and reloading seedlings, were performed between stationary points or when the devices were empty of seedlings.

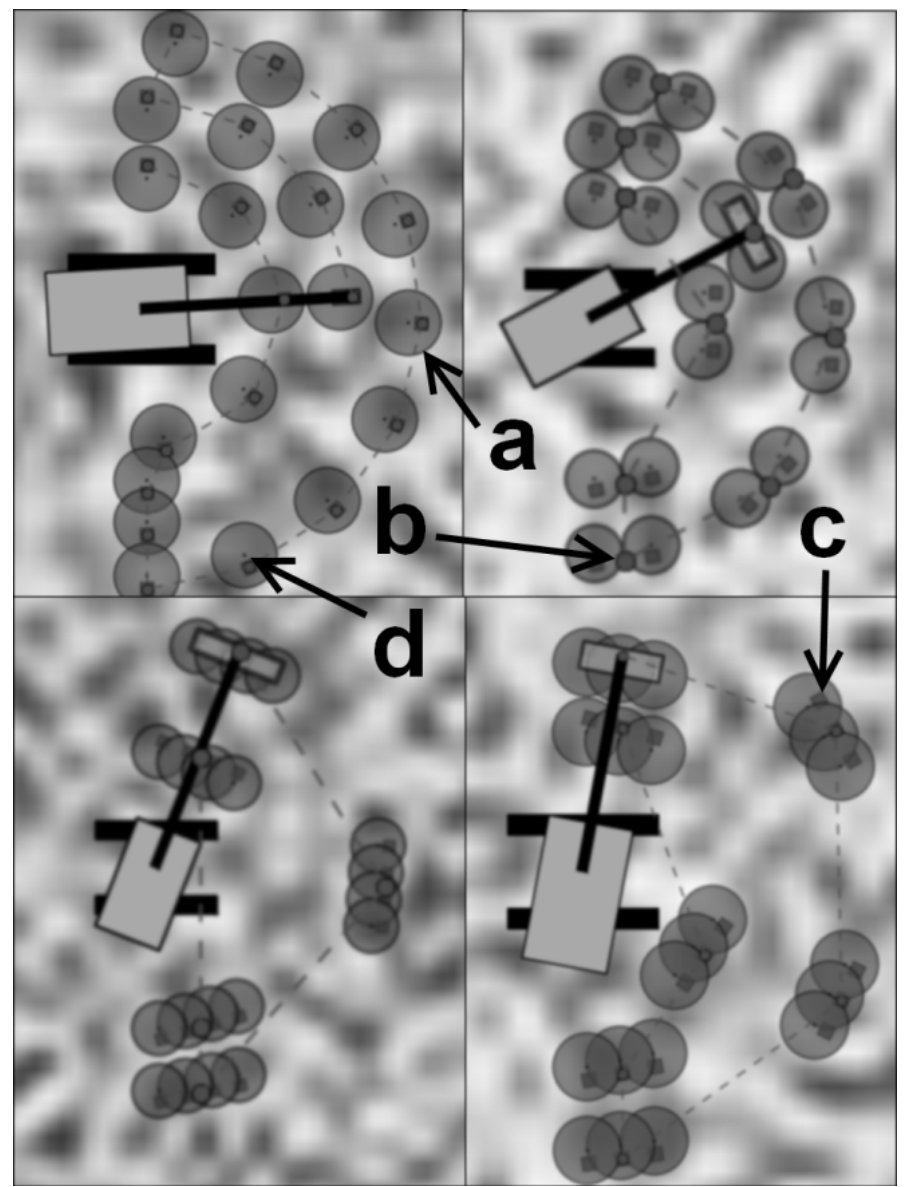

Figure 3. The ideal work patterns of the (clockwise from upper left) one-, two-, three, and four-headed planting device models on humus-covered, obstacle-free terrain as depicted by the discrete-event simulation tool's visualization feature. The dashed lines illustrate the crane motion; the radius of the large, lightly shaded circles (a) is the minimum seedling spacing; the small darker circles (b) show each crane stop; the dark squares (c) illustrate the scoops; and the tiny dots close to the scoop (d) are successfully planted seedlings. 
We modelled four generic types of planting devices (Table 2), abbreviated 1h-4h depending on the device's number of planting heads. $1 \mathrm{~h}$ and $2 \mathrm{~h}$ were modelled to be the Bracke Planter and M-Planter respectively, while $3 \mathrm{~h}$ and $4 \mathrm{~h}$ were conceptual planting devices. All device configurations had the heads linearly oriented perpendicular to the crane. The more planting heads on the planting device, the fewer the number of ideal crane stops (termed ideal planting spots, IPS, in Ersson et al. 2013) per stationary point.

The distance between planting dibbles for $3 \mathrm{~h}$ and $4 \mathrm{~h}$ was set to $1 \mathrm{~m}$. This dibble distance is half of the M-Planter's but is in accordance with the minimum seedling spacing criteria of Sweden's largest two forest owners (Mattsson \& Larsson-Stern 2009; SCA 2013). Accordingly, the minimum spacing between planted seedlings was also set to $1 \mathrm{~m}$ for all device models. The mounding blade width $\left(W_{M B}\right)$ was $40 \mathrm{~cm}$ for $1 \mathrm{~h}, 3 \mathrm{~h}$, and $4 \mathrm{~h}$, but $45 \mathrm{~cm}$ for $2 \mathrm{~h}$ (cf. Ersson et al. 2013).

Table 2. The device models' physical description and parameter values.

\begin{tabular}{cccccccc}
\hline Acronym & $\begin{array}{c}\text { Number of } \\
\text { planting } \\
\text { heads }\end{array}$ & $\begin{array}{c}\text { Seedlings } \\
\text { per reload }\end{array}$ & $\begin{array}{c}\mathrm{TC}^{*} \text { per } \\
\text { reload (s) }\end{array}$ & $\begin{array}{c}\text { Distance } \\
\text { between } \\
\text { planting } \\
\text { dibbles }(\mathrm{cm})\end{array}$ & $\begin{array}{c}\text { Total on- } \\
\text { ground } \\
\text { width }(\mathrm{cm})\end{array}$ & $\begin{array}{c}\text { Area per } \\
\text { microsite } \\
\left(\mathrm{m}^{2}\right)\end{array}$ & $\begin{array}{c}\text { Number of } \\
\text { ideal crane } \\
\text { stops per } \\
\text { stationary } \\
\text { point }\end{array}$ \\
\hline $1 \mathrm{~h}$ & 1 & $72^{\text {a) }}$ & $223^{\text {a) }}$ & - & $40^{\text {b) }}$ & 0.4 & 20 \\
$2 \mathrm{~h}$ & 2 & $162^{\mathrm{a})}$ & $366^{\mathrm{a})}$ & 201 & $247^{\mathrm{c})}$ & 2.47 & 10 \\
$3 \mathrm{~h}$ & 3 & 243 & $524^{\mathrm{d})}$ & 100 & 240 & 2.40 & 7 \\
$4 \mathrm{~h}$ & 4 & 324 & $648^{\mathrm{e})}$ & 100 & 340 & 3.40 & 5 \\
\hline
\end{tabular}

* $\mathrm{TC}=$ time consumption

a) According to Rantala et al. (2009)

b) The Bracke Planter's mounding blade width

c) Based on the M-Planter's dimensions

d) Extrapolated from Rantala et al. (2009) and Ersson et al. (2013)

e) From Ersson et al. (2013) 
Inverting task

A fifth main task was added when preparing soil using the on-ground inverting method. This task, termed inverting, entailed pushing the mound back into the scoop and took $3 \mathrm{~s}$; thus, total time consumption (TC) for the entire soil preparation task on humus-free terrain was $8 \mathrm{~s}(3 \mathrm{~s}$ to dig, 2 s to heap, 3 s invert; cf. Ersson et al. 2013).

Sundblad (2009) reported that when using the on-ground inverting method, $11 \%$ of the inverting attempts versus $5 \%$ of the mounding attempts produced non-acceptable planting spots. The non-acceptable planting spots were either too low in relation to the surrounding ground level or not capped by enough mineral soil. Consequently, we penalized inverting by requiring reinverting (gathering more mineral soil by digging and heaping; $\mathrm{TC}=5 \mathrm{~s}$ per reinvert) every ninth inverting attempt. By reinverting, we assumed that each planting spot became acceptable as long as the digging task was successful (cf. Ersson et al. 2013). Reflecting Sundblad's (2009) field observations, mounding was also penalized in this study but forced remounds ( $\mathrm{TC}=5 \mathrm{~s}$ per remound) were only required every twentieth mounding attempt. The other heads were forced to queue when individual planting heads on multi-headed devices had to remound or reinvert.

\section{The simulation model}

As in Ersson et al. (2013), each simulation run consisted of minimum 50 stationary points, the exact number depending on when the planting devices had to be reloaded with seedlings. Each stationary point was randomly allocated in the terrain model.

\section{Choosing microsites}

As in Ersson et al. (2013), the operator sought $1 \mathrm{~m} \times W_{M B}$ (for $\left.1 \mathrm{~h}\right)$ and $1 \mathrm{~m} \times W_{\text {Total }}$ (for $2 \mathrm{~h}-4 \mathrm{~h}$ ) rectangular microsites free from visible obstacles. However, since the terrain model now included surface boulders, the choosing microsite penalty ( $\mathrm{CHM}$, in seconds) for each successfully identified microsite for multi-headed devices was changed into:

$$
\mathrm{CHM}_{i}=n_{v o} \times F
$$

where $F$ is a constant with the value of 0.1 , and $n_{v o}$ is the number of visible obstacles (stumps and surface boulders) within working area $i$. 


\section{Soil preparation}

According to Finnish and Canadian follow-ups, mound height averages circa $20 \mathrm{~cm}$ when planting mechanically with the Bracke Planter (St-Amour 2009; Luoranen et al. 2011). Thus, we modelled the scoop to be $W_{M B}$-wide and $20 \mathrm{~cm}$ deep (cf. Ersson et al. 2013), and with humus layers covering the underlying soil, the mounding blades' penetration into the soil during the digging task $\left(P_{\text {soil }}\right.$, depth in $\left.\mathrm{cm}\right)$ was calculated as follows:

$$
P_{\text {soil }}=S-T_{\text {humus }}
$$

where $S$ is a constant with the value of 20, and $T_{\text {humus }}$ is the humus thickness of the microsite in $\mathrm{cm}$. Consequently, underground stones were irrelevant at microsites with $\geq 20 \mathrm{~cm}$ thick humus layers.

On the other hand, humus layers thicker than ten $\mathrm{cm}$ decrease productivity when mounding with crane-mounted planting devices (Rantala \& Laine 2010). Therefore, the TC when a planting head digs ( $T_{\text {dig }}$, in seconds) was modelled using the following deterministic function:

$$
T_{\text {dig }}=D+(y \times 0.1)
$$

where $D$ is a constant with the value of 3 , and $y$ is the microsite's humus layer thickness in $\mathrm{cm}$ exceeding ten $\mathrm{cm}$.

\section{Basic scenario and sensitivity analysis}

To test the potential productivity of our planting device models, we formulated a basic scenario in which the four devices (Table 2) reforested all five terrain models (Table 1) using mounding and with piece-wise seedling reloading. Then, all treatment combinations were rerun using instead inverting as the soil preparation method and with tray-wise seedling reloading. The latter assumed that the planting devices' seedling carousel was akin to MagMat, which meant that the reloading task's TC averaged just 1.14 s per loaded seedling (Ersson et al. 2014).

Since the EcoPlanter had flexible, obstacle-avoiding scarifying units (Mattson 1997) and a productivity of up to $600 \mathrm{pl} / \mathrm{PWh}$ (Normark \& Norr 2002), we also hypothesized lower TCs for our multi-headed device models if the planting heads also had obstacle-avoiding features.

Obstacle-avoidance meant that each planting head could, during the digging task, automatically shift sideways ten $\mathrm{cm}$ (15 cm with extra flexible heads) in either direction to avoid underground 
stones, and rotate five degrees (ten degrees with extra flexible heads) bidirectionally to avoid impeding roots (cf. Fig. 8 in Ersson et al. 2013).

Via a sensitivity analysis on terrain model 3, we explored the effect of some new parameter values for $W_{M B}$, dibble distance, $T S R$, share of remounding/reinverting, $C H M$, scoop radius, and the inverting task on the device models' TC per planted seedling (see Table 4 for the new parameter values). A dibble distance of only $0.8 \mathrm{~m}$ was tested since Salminen \& Varmola (1993) have shown that tree growth and stand characteristics are unaffected by that minimum seedling spacing. According to many field studies, optimum mound volume ranges from 10-20 L (Sutton 1993); we therefore tested a $15 \mathrm{~cm}$ scoop radius as it led to $14 \mathrm{~L}$ mounds during our simulations.

Since planting devices could be designed to use the bucket inverting method, we simulated inverting with it as well. In relation to the on-ground method, bucket inverting has shown to produce high quality planting spots but be more time consuming (Saksa et al. 2002). Based on time study results from Saksa et al. (2002), we assumed that the bucket method would only require forced reinverts every twentieth inverting attempt, and that the total TC for the entire soil preparation task on humus-free terrain was 10 or $13 \mathrm{~s}$ (to dig and invert, no heaping required).

Confidence intervals were calculated for the resulting mean values using minimum 50 replications (one stationary point equalled one replication) per treatment combination. Well over 100 treatment combinations were tested in total. We used the one-way analysis of variance (ANOVA) procedure and Tukey's HSD test to identify statistically significant differences in mean values between device models per terrain model in the basic scenario. Student's T-tests were used to test for differences in means between the basic scenario and sensitivity analysis. All tests were made in the Minitab 16 statistical package using a 95\% confidence level.

\section{Results}

\section{Time consumption per planted seedling}

In the basic scenario, time consumption (TC) on obstacle-sparse terrain (terrain models 1-2) decreased with increasing number of planting heads, but the decrease was not proportionally 
linear (Figure 4). On obstacle-sparse to moderate terrain (terrain models 1-3), TC was the lowest for $4 \mathrm{~h}$ regardless of preparing the soil using mounding or inverting. However, TC for $3 \mathrm{~h}$ was lower and more uniform than for $4 \mathrm{~h}$ on obstacle-rich terrain (terrain models 4-5). Because $4 \mathrm{~h}$ was so large, obstacle-rich terrain sometimes inhibited it from planting even one seedling at a machine stationary point, which contributed largely to $4 \mathrm{~h}$ 's high variance. Many obstacles and thin humus layers (terrain model 4 ) also increased $2 \mathrm{~h}$ 's TC to such an extent that $2 \mathrm{~h}$ was equally slow as the $1 \mathrm{~h}$-model when both mounding and inverting. Nevertheless, TC was $33-55 \%$ higher for $1 \mathrm{~h}$ compared to $2 \mathrm{~h}$ on moderate to obstacle-sparse terrain respectively.
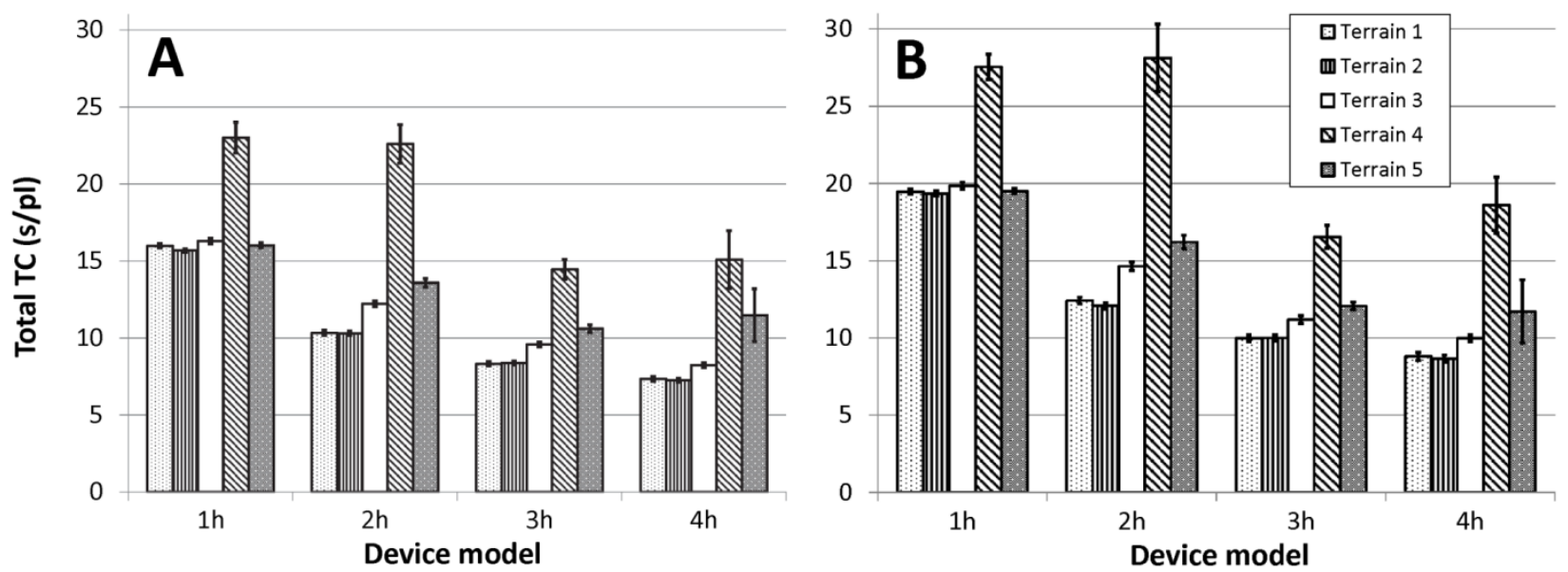

Figure 4. The mean total time consumption (TC) per planted seedling per device (1h-4h) and terrain model when mounding (A) and inverting (B). The vertical bars are the $95 \%$ confidence intervals. See Table 1 for terrain model clarification.

On moderate terrain, 4h's TC per planted seedling was the lowest among the device models for all work elements except moving base machine (Table 3). Inverting's proportion of TC remained fairly constant, $14-18 \%$ for all four device models, because the other planting heads on the multi-headed devices had to queue when one head had to reinvert. When mounding, reloading seedlings' proportion of total TC rose from circa $19 \%$ for $1 \mathrm{~h}$ to $24 \%$ for $4 \mathrm{~h}$; when inverting, these proportions shifted to circa $15 \%$ to $20 \%$ respectively. 
Table 3. Mean time consumption (TC; seconds per planted seedling, s/pl) values per device model and work element when reforesting terrain model 3 using mounding and inverting.

\begin{tabular}{|c|c|c|c|c|c|c|c|c|c|}
\hline \multirow{2}{*}{ Work task } & \multirow{2}{*}{ Work element } & \multicolumn{4}{|c|}{ Mounding } & \multicolumn{4}{|c|}{ Inverting } \\
\hline & & $1 \mathrm{~h}$ & $2 \mathrm{~h}$ & $3 \mathrm{~h}$ & $4 \mathrm{~h}$ & $1 \mathrm{~h}$ & $2 \mathrm{~h}$ & $3 \mathrm{~h}$ & $4 \mathrm{~h}$ \\
\hline \multirow[t]{5}{*}{ Main task } & Moving crane & 2.98 & 2.25 & 1.85 & 1.65 & 3.04 & 2.24 & 1.84 & 1.72 \\
\hline & $\begin{array}{l}\text { Choosing } \\
\text { microsite }\end{array}$ & 0.00 & 1.65 & 1.13 & 0.83 & 0.00 & 1.64 & 1.12 & 0.84 \\
\hline & $\begin{array}{l}\text { Mounding } \\
\text { (incl. halting } \\
\text { mounding and } \\
\text { remounding) }\end{array}$ & 5.67 & 3.05 & 2.09 & 1.64 & 5.56 & 3.02 & 2.11 & 1.71 \\
\hline & $\begin{array}{l}\text { Inverting (incl. } \\
\text { reinverting } \\
\text { attempts) }\end{array}$ & - & - & - & - & 3.60 & 2.48 & 1.64 & 1.52 \\
\hline & $\begin{array}{l}\text { Planting (incl. } \\
\text { halting } \\
\text { planting and } \\
\text { reattempts) }\end{array}$ & 3.28 & 1.75 & 1.16 & 0.86 & 3.31 & 1.74 & 1.14 & 0.92 \\
\hline \multirow[t]{2}{*}{$\begin{array}{l}\text { Secondary } \\
\text { task }\end{array}$} & $\begin{array}{l}\text { Moving base } \\
\text { machine }\end{array}$ & 1.25 & 1.25 & 1.25 & 1.26 & 1.25 & 1.26 & 1.25 & 1.26 \\
\hline & $\begin{array}{l}\text { Reloading } \\
\text { seedlings }\end{array}$ & 3.10 & 2.26 & 2.09 & 2.00 & 3.10 & 2.26 & 2.09 & 2.00 \\
\hline All pooled & All pooled & 16.28 & 12.21 & 9.57 & 8.23 & 19.86 & 14.63 & 11.18 & 9.97 \\
\hline
\end{tabular}

When $1 \mathrm{~h}$ was modelled to have a tray-wise-loaded seedling carousel, mean TC was reduced by $11-13 \%$ (reductions always significant at a 95\% confidence level) when mounding on obstacle-rich to obstacle-sparse terrain respectively. The corresponding decrease in mean TC for tray-wise-loaded multi-headed devices $(2 \mathrm{~h}-4 \mathrm{~h})$ when mounding was 3-12\% (reductions were significant for all three device models on terrain models 1-3 but not terrain models 4 and 5). When inverting, tray-wise loading reduced the mean TC of all four device models by $7-11 \%$ on terrain models 1, 2, 3, and 5 (always significant except for $4 \mathrm{~h}$ on terrain model 5), but reductions were not significant on terrain model 4 . Thus, the relative time savings because of tray-wise seedling reloading lessened with increasingly difficult terrain (results not shown). 
Generally, modelling the device models with obstacle-avoiding features did not lead to any significant decreases in mean TC for any device on any terrain model. The only exception was $2 \mathrm{~h}$ with extra flexible heads when inverting on terrain model 3 , this configuration significantly lowered mean TC but the reduction was slight (less than $0.5 \mathrm{~s}$; results not shown).

\section{Sensitivity analysis}

Widening the distance between planting dibbles to $1.5 \mathrm{~m}$ on $3 \mathrm{~h}$ and $4 \mathrm{~h}$ significantly increased their mean TC when mounding, while lessening the distance had no significant effect (Table 4). Decreasing the TSR by $500 \mathrm{pl} / \mathrm{ha}$ always led to significantly higher TC, while a TSR of 2500 $\mathrm{pl} / \mathrm{ha}$ significantly lowered mean TC for all device models except $4 \mathrm{~h}$. Meanwhile, no forced remounding led only to significantly lower TC for $1 \mathrm{~h}$ (results for inverting not shown).

Modifying the inverting task's TC or using the bucket inverting method generally led to significantly different mean total TC compared to the basic scenario (Table 5). The foremost exception here, however, was that inverting with the bucket method taking $10 \mathrm{~s}$ per invert was not significantly slower for $3 \mathrm{~h}$ and $4 \mathrm{~h}$.

\section{Planting device productivity}

In general, device productivity increased significantly with increasing numbers of planting heads regardless of soil preparation method (Figure 5). However, $4 \mathrm{~h}$ was not more productive than $3 \mathrm{~h}$ on obstacle-rich terrain, and $2 \mathrm{~h}$ was not more productive than $1 \mathrm{~h}$ on terrain model 4 . Still, $3 \mathrm{~h}$ was significantly more productive than $2 \mathrm{~h}$ on all terrain models.

Inverting resulted in circa $16 \%$ lower productivity on average compared to mounding for all four device models on all terrain types (Figure 5B). Both when mounding and inverting, 4h's average productivity advantage over $3 \mathrm{~h}$ for all terrain types was circa $6 \%$.

One of the main reasons why $3 \mathrm{~h}$ was as equally productive as $4 \mathrm{~h}$ on obstacle-rich terrain was 4h's larger size, which prevented the device model from finding enough acceptable microsites per stationary point. This disadvantage led, in turn, $4 \mathrm{~h}$ to plant significantly fewer seedlings per ha than $3 \mathrm{~h}$ on such terrain (Figure 6). $2 \mathrm{~h}$ also planted significantly fewer seedlings than $3 \mathrm{~h}$ on obstacle-rich terrain because $2 \mathrm{~h}$ only planted two seedlings per acceptable microsite despite having equally large dimensions as $3 \mathrm{~h}$. 

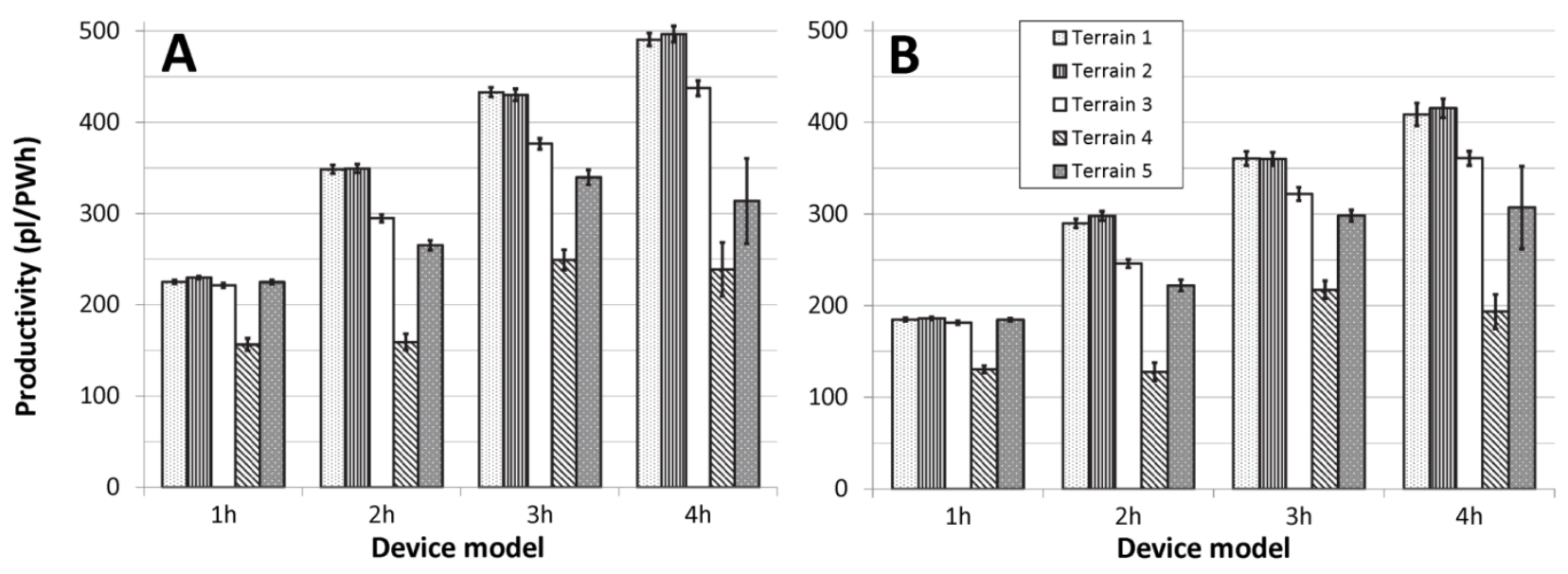

Figure 5. The mean productivity (planted seedlings per productive work hour) for one- to four-headed planting devices (1h-4h) on the five terrain models when mounding (A) and inverting (B). The vertical bars are the $95 \%$ confidence intervals. See Table 1 for terrain model clarification.

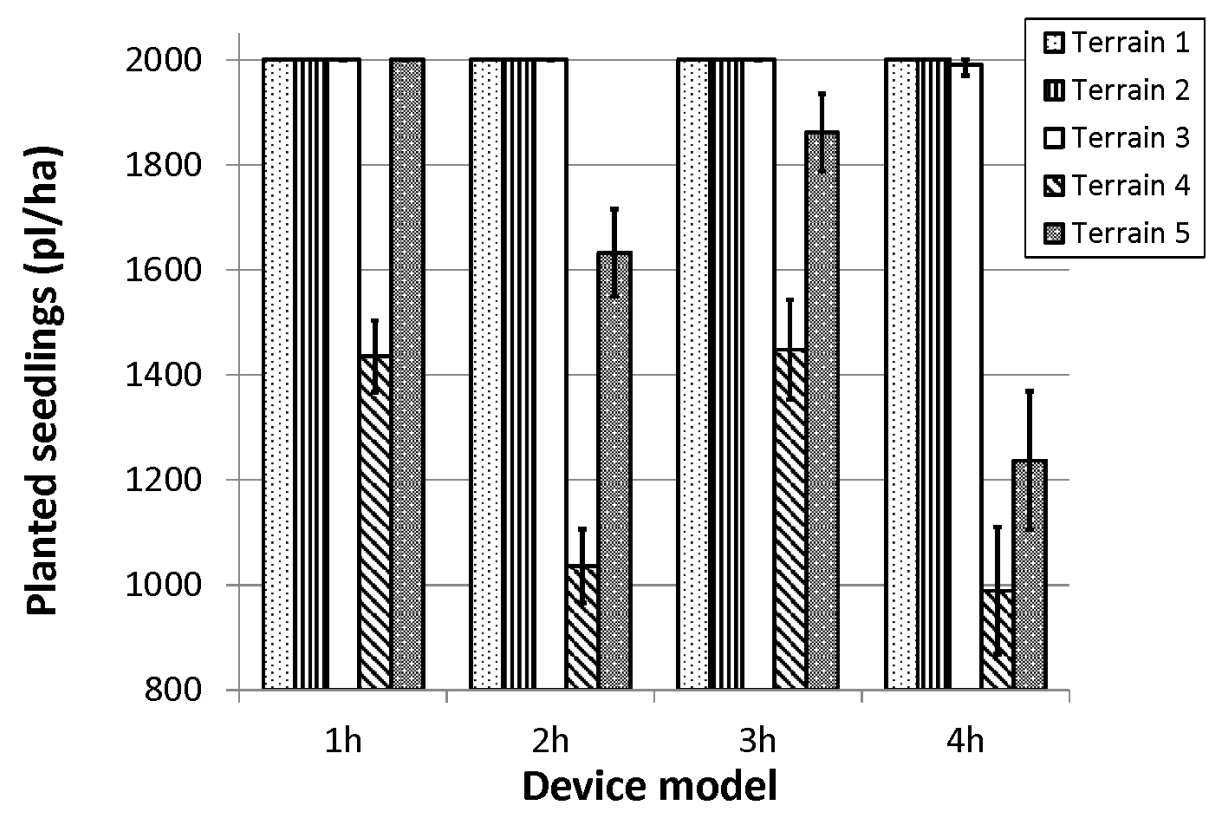

Figure 6. The mean number of planted seedlings per ha by the one- to four-headed planting devices (1h$4 \mathrm{~h}$ ) on the five terrain models. The vertical bars are the $95 \%$ confidence intervals. See Table 1 for terrain model clarification. Note: the y-axis has been truncated. 
Table 4. The effect of changing the parameter values used in the basic scenario on the mean time consumption (TC; s/pl) of one- to four-headed planting devices when reforesting terrain model 3 using mounding.

\begin{tabular}{|c|c|c|c|c|c|c|c|}
\hline \multirow[b]{2}{*}{ Parameter (unit) } & \multicolumn{2}{|c|}{ Value } & \multirow{2}{*}{$\begin{array}{c}\text { Planting } \\
\text { device } \\
\text { model } \\
\end{array}$} & \multicolumn{4}{|c|}{$\mathrm{TC}(\mathrm{s} / \mathrm{pl})$ when mounding } \\
\hline & $\begin{array}{c}\text { Basic } \\
\text { scenario }\end{array}$ & New & & Mean & Minimum & Maximum & SD \\
\hline \multirow{5}{*}{$\begin{array}{l}\text { Mounding blade width } \\
\left(W_{M B}, \mathrm{~cm}\right)\end{array}$} & 40 & 60 & $1 \mathrm{~h}$ & 17.19 & 15.40 & 19.74 & 1.14 \\
\hline & $45^{\mathrm{a})}$ & 60 & $2 \mathrm{~h}$ & 12.55 & 11.00 & 14.93 & 0.73 \\
\hline & 40 & 60 & $3 \mathrm{~h}$ & 9.82 & 8.88 & 11.96 & 0.60 \\
\hline & 40 & 60 & $4 \mathrm{~h}$ & 8.75 & 7.54 & 9.84 & 0.53 \\
\hline & $45^{\text {a) }}$ & 40 & $2 \mathrm{~h}$ & 12.01 & 10.77 & 13.11 & 0.57 \\
\hline \multirow{4}{*}{$\begin{array}{l}\text { Dibble distance on } 3 \mathrm{~h}- \\
4 \mathrm{~h}(\mathrm{~m})\end{array}$} & 1 & 1.5 & $3 \mathrm{~h}$ & 9.89 & 8.80 & 12.67 & 0.68 \\
\hline & 1 & 1.5 & $4 \mathrm{~h}$ & 9.70 & 7.23 & 24.16 & 2.16 \\
\hline & 1 & 0.8 & $3 \mathrm{~h}$ & 9.50 & 8.58 & 11.27 & 0.52 \\
\hline & 1 & 0.8 & $4 \mathrm{~h}$ & 8.41 & 7.64 & 10.09 & 0.48 \\
\hline \multirow{8}{*}{$\begin{array}{l}\text { Target stocking rate } \\
(T S R, \mathrm{pl} / \mathrm{ha})\end{array}$} & 2000 & 1500 & $1 \mathrm{~h}$ & 17.13 & 15.84 & 19.49 & 0.72 \\
\hline & 2000 & 1500 & $2 \mathrm{~h}$ & 13.07 & 11.45 & 15.16 & 0.90 \\
\hline & 2000 & 1500 & $3 \mathrm{~h}$ & 10.36 & 9.05 & 12.45 & 0.64 \\
\hline & 2000 & 1500 & $4 \mathrm{~h}$ & 9.07 & 7.87 & 10.89 & 0.61 \\
\hline & 2000 & 2500 & $1 \mathrm{~h}$ & 15.88 & 14.58 & 16.96 & 0.61 \\
\hline & 2000 & 2500 & $2 \mathrm{~h}$ & 11.64 & 10.54 & 13.01 & 0.56 \\
\hline & 2000 & 2500 & $3 \mathrm{~h}$ & 9.19 & 8.49 & 10.74 & 0.47 \\
\hline & 2000 & 2500 & $4 \mathrm{~h}$ & 8.04 & 7.12 & 9.69 & 0.46 \\
\hline \multirow{4}{*}{$\begin{array}{l}\text { No remounding } \\
\text { (proportion of } \\
\text { remounds per } \\
\text { mounding attempt, \%) }\end{array}$} & 5 & 0 & $1 \mathrm{~h}$ & 16.75 & 15.34 & 19.17 & 0.94 \\
\hline & 5 & 0 & $2 \mathrm{~h}$ & 12.23 & 10.82 & 15.37 & 0.89 \\
\hline & 5 & 0 & $3 \mathrm{~h}$ & 9.49 & 8.43 & 10.95 & 0.60 \\
\hline & 5 & 0 & $4 \mathrm{~h}$ & 8.33 & 7.35 & 9.47 & 0.44 \\
\hline \multirow{3}{*}{$\begin{array}{l}\text { No choosing microsite } \\
\text { time penalty }(C H M) \text { for } \\
2 \mathrm{~h}-4 \mathrm{~h} \text { (s per visible } \\
\text { obstacle) }\end{array}$} & 0.1 & 0 & $2 \mathrm{~h}$ & 10.44 & 9.12 & 11.61 & 0.50 \\
\hline & 0.1 & 0 & $3 \mathrm{~h}$ & 8.48 & 7.50 & 9.85 & 0.52 \\
\hline & 0.1 & 0 & $4 h$ & 7.43 & 6.39 & 8.39 & 0.47 \\
\hline \multirow{4}{*}{$\begin{array}{l}\text { Smaller scoop/mound } \\
\text { radius }(\mathrm{cm})\end{array}$} & 20 & 15 & $1 \mathrm{~h}$ & 15.92 & 14.86 & 17.16 & 0.57 \\
\hline & 20 & 15 & $2 \mathrm{~h}$ & 11.75 & 10.53 & 13.39 & 0.63 \\
\hline & 20 & 15 & $3 \mathrm{~h}$ & 9.45 & 8.38 & 11.14 & 0.53 \\
\hline & 20 & 15 & $4 \mathrm{~h}$ & 8.26 & 7.18 & 9.52 & 0.61 \\
\hline
\end{tabular}

a) The mounding blade width of $2 \mathrm{~h}$ (M-Planter) was $45 \mathrm{~cm}$.

Note: a bold mean value indicates that it is, with a $95 \%$ confidence level, significantly different from the basic scenario's mean value scenario (see total TC value for mounding in Table 3 ). 
Table 5. The time consumption (TC; s/pl) of one- to four-headed device models (1h-4h) when inverting on terrain model 3 using the on-ground and bucket inverting methods.

\begin{tabular}{lccccc}
\hline & & \multicolumn{4}{c}{ TC (s/pl) when inverting } \\
\cline { 3 - 6 } Parameter & $\begin{array}{c}\text { Planting } \\
\text { device model }\end{array}$ & Mean & Minimum & Maximum & SD \\
\hline On-ground inverting, 1s for & $1 \mathrm{~h}$ & $\mathbf{1 7 . 8 6}$ & 16.01 & 19.24 & 0.70 \\
inverting task & $2 \mathrm{~h}$ & $\mathbf{1 3 . 1 0}$ & 11.32 & 15.89 & 0.88 \\
& $3 \mathrm{~h}$ & $\mathbf{1 0 . 6 1}$ & 9.30 & 13.84 & 0.89 \\
& $4 \mathrm{~h}$ & $\mathbf{9 . 2 3}$ & 7.47 & 12.95 & 1.13 \\
On-ground inverting, 5s for & $1 \mathrm{~h}$ & $\mathbf{2 1 . 9 9}$ & 20.61 & 25.16 & 0.91 \\
inverting task & $2 \mathrm{~h}$ & $\mathbf{1 5 . 2 7}$ & 13.57 & 17.50 & 0.84 \\
& $3 \mathrm{~h}$ & $\mathbf{1 1 . 7 8}$ & 10.50 & 13.57 & 0.70 \\
& $4 \mathrm{~h}$ & 10.36 & 8.40 & 12.94 & 0.92 \\
Bucket inverting, 10s for entire & $1 \mathrm{~h}$ & $\mathbf{2 1 . 7 0}$ & 20.04 & 24.24 & 0.77 \\
soil preparation task & $2 \mathrm{~h}$ & $\mathbf{1 5 . 2 0}$ & 13.26 & 18.94 & 0.83 \\
& $3 \mathrm{~h}$ & 11.45 & 10.16 & 13.03 & 0.69 \\
& $4 \mathrm{~h}$ & 9.97 & 8.49 & 11.74 & 0.86 \\
Bucket inverting, 13s for entire & $1 \mathrm{~h}$ & $\mathbf{2 5 . 0 1}$ & 23.37 & 27.25 & 0.99 \\
soil preparation task & $2 \mathrm{~h}$ & $\mathbf{1 6 . 6 7}$ & 14.81 & 18.64 & 0.87 \\
& $3 \mathrm{~h}$ & $\mathbf{1 2 . 5 9}$ & 10.79 & 14.24 & 0.73 \\
& $4 \mathrm{~h}$ & $\mathbf{1 0 . 9 7}$ & 9.21 & 12.86 & 0.80 \\
\hline
\end{tabular}

Note: a bold mean value indicates that it is, with a $95 \%$ confidence level, significantly different from that device model's mean value in the basic scenario (see total TC value for inverting in Table 3 ). The basic scenario assumed the on-ground inverting method and that the inverting task took $3 \mathrm{~s}$.

\section{Discussion}

Planting device productivity increased with increasing numbers of planting heads on obstaclesparse and moderate terrain, but not on obstacle-rich terrain. Instead, 3h was more productive than $4 \mathrm{~h}$ on difficult terrain, and showed significantly higher productivity than $2 \mathrm{~h}$ on all terrain types, regardless of soil preparation and seedling reloading system. Furthermore, $3 \mathrm{~h}$ consistently planted significantly more seedlings per ha than both $2 \mathrm{~h}$ and $4 \mathrm{~h}$ on obstacle-rich terrain.

Our finding that planting device productivity increases with multi-headed configurations is supported by previous studies of two-headed planting devices, both empirical (Mattson 1997; Rantala et al. 2009) and theoretical (Rummukainen et al. 2003; Ersson et al. 2013). The results of Rantala et al. (2009) and Ersson et al. (2014, p. 9) support our findings that increasing obstacle- 
density reduces the productivity gain of more planting heads and faster seedling reloading solutions, respectively.

Even though $4 \mathrm{~h}$ was the most productive model on obstacle-sparse and moderate terrain, we believe that its poor performance on difficult terrain won't make it feasible in real-life. There are often obstacle-rich areas even on moderate clearcuts, and not being able to plant even one seedling per machine stationary point (circa $100 \mathrm{~m}^{2}$ ) would probably not be acceptable for forest owners. Moreover, $4 \mathrm{~h}$ would most certainly have a higher purchase price and perhaps require a larger base machine than $3 \mathrm{~h}$, which would further lower the cost-competitiveness of four-headed planting devices versus three-headed varieties.

Obstacle-avoiding features did not significantly lower TC but we did not model the extraflexible configuration on obstacle-rich terrain (terrain model 4 and 5) on which they might have been most beneficial. Also, we assumed that devices having obstacle-avoiding features required a $20 \mathrm{~cm}$ (30 cm with extra flexible heads) wider microsite area (Figure 7, ObAv-models). This assumption probably reduced these devices' competitiveness but might not necessarily be realistic.

According to Hallsby \& Örlander (2004), inverting results in $20 \%$ higher seedling survival rates compared to mounding on mesic sites in Sweden (78\% versus $65 \%$ respectively five years after planting). Higher seedling survival rates could translate into lower target stocking rates (TSR) which in turn can 1) reduce the number of seedlings planted per machine stationary point, and/or 2) increase the distance between each machine stationary point ( $S_{B M}$, cf. Ersson et al. 2013). In our basic scenario, $20 \%$ higher seedling survival would allow for a TSR of only $1667 \mathrm{pl} / \mathrm{ha}$ when inverting compared to $2000 \mathrm{pl} / \mathrm{ha}$ when mounding. Since creating the maximum number of planting spots per stationary point maximizes productivity when working with excavator-mounted scarifying devices (von der Gönna 1992), we could assume that inverting on mesic sites entails the same number of planted seedlings per stationary point but longer $S_{B M}(6 \mathrm{~m}$ vs $7.2 \mathrm{~m}$ for mounding and inverting respectively). Compared to mounding, a lower TSR and longer $S_{B M}$ actually reduced the TC per ha (PWh/ha) by $3-6 \%$ when inverting with $3 \mathrm{~h}$ and $4 \mathrm{~h}$ on difficult terrain, while staying the same or increasing by $1-4 \%$ for all other combinations of terrain and planting devices. Hence, despite lower productivity, multi-headed planting devices that invert could be justified as a means of reducing mechanized stand regeneration costs, especially on obstacle-rich mesic sites and in regions where seedling purchase prices are high. 
On-ground inverting was developed as a method of increasing inverting productivity compared to the bucket method (Nilsson et al. 2010). Yet on-ground inverting increases soil disturbance compared to the bucket method (cf. Sundblad 2009) since the mound including its underlying humus is pushed back into the scoop. This extra soil disturbance is probably the reason for the on-ground method's relatively high proportion of non-acceptable planting spots. Our results show, however, that the bucket method is a reasonable choice of inverting method for $3 \mathrm{~h}$ and $4 \mathrm{~h}$ if the entire soil preparation task can be performed in maximum 10s.

Compared to previous time studies of the Bracke Planter, our simulation results for $1 \mathrm{~h}$ overestimated productivity on moderate terrain by only 1.4\% (Engqvist \& Moretoft 1993) while underestimating productivity on obstacle-sparse (von Hofsten 1993; Rantala et al. 2009, maximum measured productivity of driver D0) and obstacle-rich terrain (Saarinen 2006, Karttula site) by 7.7-15.4\%. Meanwhile, our mean productivity figures for $2 \mathrm{~h}$ on obstacle-sparse terrain were only $1 \%$ lower and $3 \%$ higher than the maximum productivity of the M-Planter device measured by Rantala et al. (2009, driver D1) and Laine \& Rantala (2013, operator F, including seedling reloading) respectively. This study's productivity figures for $1 \mathrm{~h}$ and $2 \mathrm{~h}$ were lower than those of Ersson et al. (2013). The main reasons for this decrease were probably this study's larger underground stones and addition of surface boulders, which affected especially $2 \mathrm{~h}$ by e.g. more than quintupling the choosing microsite task's TC on moderate terrain. Nonetheless, we judge that these differences between our modelled and previously reported productivities for $1 \mathrm{~h}$ and $2 \mathrm{~h}$ do not affect the validity of our inter-device model comparisons.

The operator is one of the key factors affecting the productivity of today's crane-mounted planting devices (Rantala et al. 2009; Rantala \& Laine 2010; Laine \& Rantala 2013). In our simulations, a skilled operator could be modelled as having no CHM (i.e. the F-constant's value is 0 in equation 1). Without any CHM, the total TC for multi-headed devices decreased by 10$15 \%$ (Table 4), with $2 \mathrm{~h}$ enjoying greater time savings than $3 \mathrm{~h}$ and $4 \mathrm{~h}$. Equally important, we might reasonably assume a steeper learning curve for operators using $3 \mathrm{~h}$ and $4 \mathrm{~h}$, seeing that they represent more complex tools compared to $2 \mathrm{~h}$ and especially $1 \mathrm{~h}$.

One uncertainty with our results is that we did not test all possible combinations of e.g. two-headed devices. A narrower version of $2 \mathrm{~h}$, with $1 \mathrm{~m}$ dibble distance, might have been competitive, especially on obstacle-rich terrain since its required microsite area would be small (Figure 7). Also, the devices' geometrical design is important, and there are other designs for $3 \mathrm{~h}$ 
and $4 \mathrm{~h}$ that weren't simulated. For example, 3h Triangle and $4 \mathrm{~h}$ Square would require less microsite area than our linearly-arranged $3 \mathrm{~h}$ - and $4 \mathrm{~h}$-models and give each seedling more growing space compared to the innermost seedlings planted by our $3 \mathrm{~h}$ - and $4 \mathrm{~h}-$ models (cf. the Voronoi polygons of Lundqvist \& Elfving 2010). In Figure 7, we calculated $3 \mathrm{~h}$ Triangle and $4 \mathrm{~h}$ Square's microsite area only with $1 \mathrm{~m}$ dibble distance since our simulation results indicated no significant productivity gain with $0.8 \mathrm{~m}$ dibble distance. One potential disadvantage with $4 \mathrm{~h}$ Square is that it would probably prevent the operator from seeing all planting heads during the on-ground work. The $3 \mathrm{~h}$ Triangle could be designed to allow full view of the planting heads by arranging the triangle so that an apex points towards the cab. Nevertheless, this study probably highlights the productivity limits of realistic boom-tip planting device configurations. In other words, if four-headed devices aren't worth it, five- and six-headed devices won't be either. Consequently, continuously advancing planting machines are probably necessary to achieve productivities higher than those of three- and four-headed crane-mounted devices (cf. Hallonborg et al. 1995; Saarinen et al. 2013).

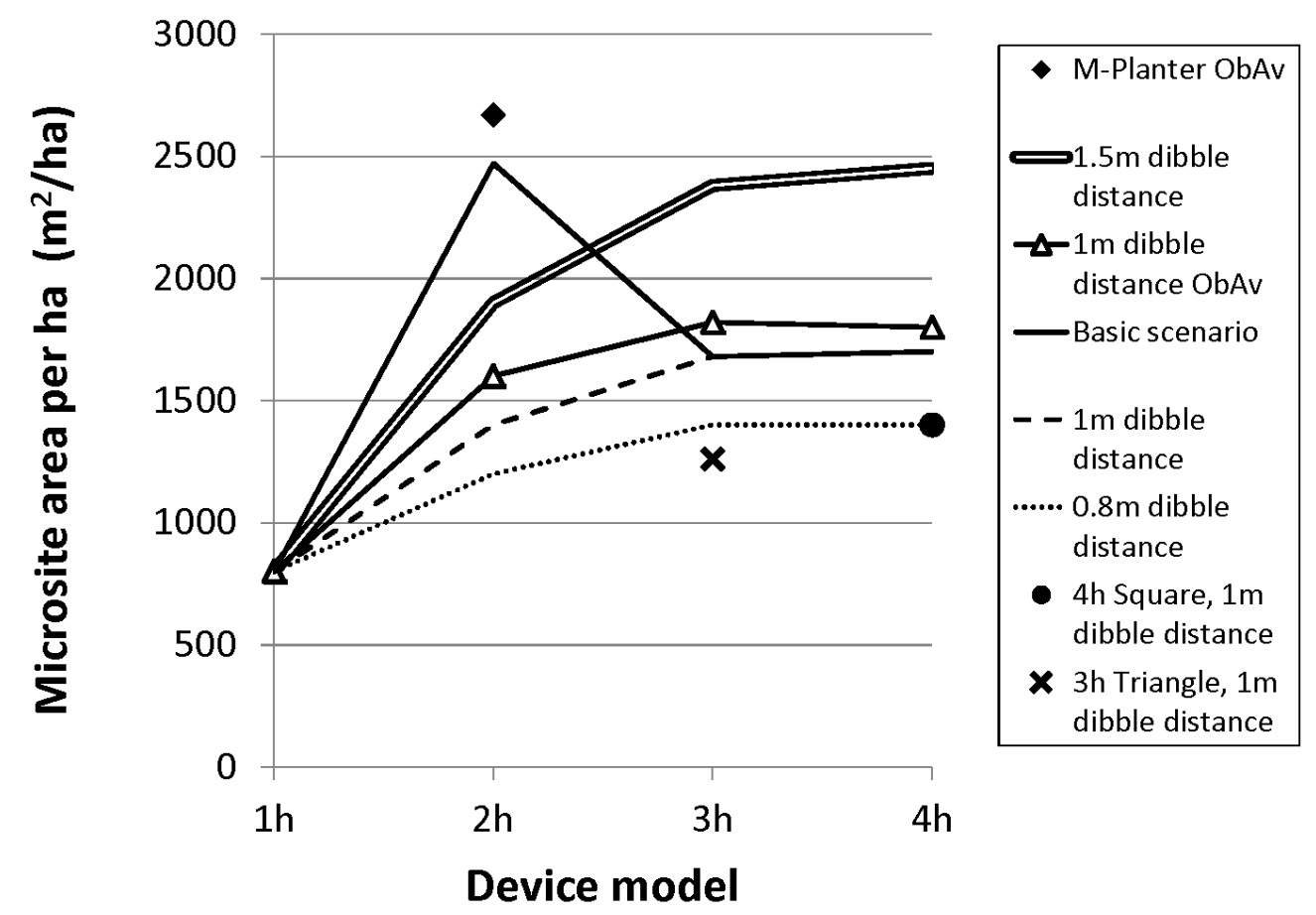

Figure 7. The area required by various planting device models to find 2000 acceptable microsites per ha assuming $40 \mathrm{~cm}$ mounding blade width (except for the M-Planter device models which assumed $45 \mathrm{~cm}$ wide mounding blades). ObAv $=$ having obstacle-avoiding features. Note: $3 \mathrm{~h}$ Triangle, $4 \mathrm{~h}$ Square, and $2 \mathrm{~h}$-configurations with $<2 \mathrm{~m}$ dibble distances were not simulated in this study. 


\section{Conclusions}

Based on our simulation results, three planting heads per crane-mounted device seems to be the optimum when balancing high productivity with acceptable silvicultural results on all the terrain types that a planting machine might work on in Fennoscandia. Faster seedling reloading when working on difficult terrain served only to increase three-headed devices' competitiveness, while slower soil preparation methods (inverting) had no effect on it.

That said, four-headed devices could perhaps be better than three-headed devices if they can be kept small via optimized geometrical design and the area required for acceptable microsites can be kept equal to the three-headed devices' area requirement. However, such fourheaded devices would most likely require very short dibble distances ( $1 \mathrm{~m}$ or less), which might result in excessive silvicultural disadvantages because of clumping (Stiell 1982; Lundqvist \& Elfving 2010).

\section{Acknowledgements}

This study was funded by Södra Skog, Sveaskog, and SLU's Faculty of Forest Sciences through the FIRST research school. The computer programming was supported in part by the European Regional Development Fund and the UMIT Research Lab. 


\section{References}

Åhlund J. 1995. Mekaniserad plantering med ECO-Planter 2000 - en prestationsstudie samt systemjämförelse med Silva Nova och manuell plantering [Mechanised forest planting - a study of ECO-Planter 2000 planting machine and a comparison with Silva Nova planting machine and manual planting systems]. Institutionen för skogsteknik, SLU, Garpenberg. Studentuppsatser nr 29.

Andersson P-O, Berglund H, Bäckström P-O. 1977. Simulering av maskinella planteringsorgans arbete [Simulating the operation of mechanized planting units]. Forskningsstiftelsen Skogsarbeten. Redogörelse nr 7.

Asikainen A. 1995. Discrete-event simulation of mechanized wood-harvesting systems. Faculty of Forestry, University of Joensuu. Dissertation.

Bäckström PO. 1978. Mechanized planting - Basic conditions, techniques, productivity and costs. Forskningstiftelsen Skogsarbeten. Meddelande.

Berg S. 1982. Terrängtypschema [Terrain Classification System for Forestry Work]. Forskningsstiftelsen Skogsarbeten.

Davidsson A. 2002. Utvärdering av granplantering i rektangelförband jämfört med kvadratförband [Evaluation of spruce planting in rectangular spacing compared to square spacing]. Institutionen för skogsskötsel, SLU. Examensarbeten 2002-2.

Engqvist M, Moretoft M. 1993. Tidsstudie och produktionsuppföljning på Öje-Planter sommaren 1993 [Time study and production follow-up of an Öje-Planter during summer 1993]. Norra Skogsinstitutet, SLU. Fördjupningsuppgift.

Eriksson T. 2013. Silviculture and Environmental Consideration. In: Skogsstatistisk Årsbok [Swedish Statistical Yearbook of Forestry]. Skogsstyrelsen [Swedish Forest Agency]. p. $112-148$.

Ersson BT. 2010. Possible Concepts for Mechanized Tree Planting in Southern Sweden - An Introductory Essay on Forest Technology. Department of Forest Resource Management, SLU. Arbetsrapport 269. ISSN 1401-1204. ISRN SLU-SRG-AR-269-SE.

Ersson BT, Bergsten U, Lindroos O. 2014. Reloading mechanized tree planting devices faster using a seedling tray carousel. Silva Fennica. 48:article id 1064.

Ersson BT, Junden L, Bergsten U, Servin M. 2013. Simulated productivity of one- and twoarmed tree planting machines. Silva Fennica. 47:article id 958. 
Ersson BT, Petersson M. 2013a. Uppföljning av planteringsmaskinen 2013 - färska planteringar [Follow-up of the planting machine year 2013- freshly planted seedlings]. Skoglig Service, Södra Skog. Rapport S50.

Ersson BT, Petersson M. 2013b. Återinventering av 2010 års maskinplanteringar - 3-års uppföljning [Three-year follow-up of 2010's mechanically planted seedlings]. Skoglig service, Södra Skog. Rapport S048.

von der Gönna MA. 1992. Excavator attachments for site preparation in British Columbia. Forest Engineering Research Institute of Canada. Technical Note. TN-180.

Granhus A, Brække FH, Hanssen KH, Haveraaen O. 2003. Effects of partial cutting and scarification on planted Picea abies at mid-elevation sites in south-east Norway. Scandinavian Journal of Forest Research. 18:237-246.

Hallonborg U. 1997. Aspects of Mechanized Tree Planting. SLU. Acta Universitatis Agriculturae Sueciae Silvestria 29.

Hallonborg U, von Hofsten H, Mattson S, Hagberg J, Thorsén Å, Nyström C, Arvidsson H. 1995. Maskinell plantering med Silva Nova -nuvarande status samt utvecklingsmöjligheter i jämförelse med manuell plantering [Mechanized planting with the Silva Nova tree planter -recent state and feasibility compared with manual planting]. Skogforsk. Redogörelse nr 6.

Hallonborg U, von Hofsten H, Mattsson S, Thorsén Å. 1997. Forestry planting machines - a description of the methods and the machines. Skogforsk. Redogörelse. nr 7.

Hallongren H, Laine T, Rantala J, Saarinen V-M, Strandström M, Hämäläinen J, Poikela A. 2014. Competitiveness of mechanized tree planting in Finland. Scandinavian Journal of Forest Research. 29:144-151.

Hallsby G, Örlander G. 2004. A comparison of mounding and inverting to establish Norway spruce on podzolic soils in Sweden. Forestry. 77:107-117.

Härkönen M. 2008. M-Planter- ja Bräcke-istutuskoneiden työn laatu [Work quality of M-Planter and Bräcke forest planting machines]. Faculty of Forest Sciences, University of Joensuu. M.Sc. thesis.

Heiskanen J, Saksa T, Luoranen J. 2013. Soil preparation method affects outplanting success of Norway spruce container seedlings on till soils susceptible to frost heave. Silva Fennica. 47. 
Herlitz A. 1975. Typbestånd i slutavverkning [Typestands for clear cutting]. Institutionen för skogsteknik. Skogshögskolan. Rapport Nr 81.

von Hofsten H. 1993. Hög kvalitet även på högkvaliteten med Öje-Planter [The Öje Planter machine - good performance at a competitive cost]. Skogforsk. Resultat nr 3.

Huuri O. 1972. The effect of deviating planting techniques on initial development of seedlings of Scots pine and Norway spruce. Communicationes Instituti Forestalis Fenniae. 75.6.

Johansson K, Nilsson U, Örlander G. 2013. A comparison of long-term effects of scarification methods on the establishment of Norway spruce. Forestry. 86:91-98.

Jundén L. 2011. Discrete Event Simulations in Forest Technology. Department of Physics/UMIT Research Lab, Umeå University. Master's Thesis.

Jundén L, Bergström D, Servin M, Bergsten U. 2013. Simulation of Boom-Corridor Thinning using a Double-Crane System and Different Levels of Automation. International Journal of Forest Engineering. 24:16-23.

Juntunen M-L, Herrala-Ylinen H. 2013. Silviculture. In: Metsätilastollinen vuosikirja [Finnish Statistical Yearbook of Forestry]. Metla [Finnish Forest Research Institute]. p. 103-146.

Laine T, Rantala J. 2013. Mechanized tree planting with an excavator-mounted M-Planter planting device. International Journal of Forest Engineering. 24:183-193.

Larsson T. 1976. Blockförekomst i skogsmark [Occurence of stones in forest soils]. Forskningsstiftelsen Skogsarbeten. Ekonomi nr 4.

Lindman J, Näslund B-Å, Olsson P, Samuelsson H. 1985. Radförband [Rectangular Line Planting]. Forskningsstiftelsen Skogsarbeten. Redogörelse nr 8.

Löf M, Dey DC, Navarro RM, Jacobs DF. 2012. Mechanical site preparation for forest restoration. New Forests. 43:825-848.

Lundqvist L, Elfving B. 2010. Influence of biomechanics and growing space on tree growth in young Pinus sylvestris stands. Forest Ecology and Management. 260:2143-2147.

Luoranen J, Rikala R, Smolander H. 2011. Machine planting of Norway spruce by Bracke and Ecoplanter: an evaluation of soil preparation, planting method and seedling performance. Silva Fennica. 45:341-357.

Mattson S. 1997. EcoPlanter, planteringsmaskin med fräs [The EcoPlanter: a mounder-equipped planting machine]. Skogforsk. Resultat nr 4.

Mattsson S, Larsson-Stern M. 2009. Instruktion för plantering [Planting instructions]. Sveaskog. 
Nieuwenhuis M, Egan D. 2002. An Evaluation and Comparison of Mechanised and Manual Tree Planting on Afforestation and Reforestation Sites in Ireland. International Journal of Forest Engineering. 13:11-23.

Nilsson U, Luoranen J, Kolström T, Örlander G, Puttonen P. 2010. Reforestation with planting in northern Europe. Scandinavian Journal of Forest Research. 25:283-294.

Normark E. 2011. Riktlinjer för uthålligt skogsbruk [Guidelines for sustainable forest managemant]. Holmen Skog.

Normark E, Norr M. 2002. EcoPlanter - sammanställning av ett utvecklingsprojekt [EcoPlanter a compilation of the development project]. Skogsvårdsavdelningen, Holmen Skog.

Olsson MT, Erlandsson M, Lundin L, Nilsson T, Nilsson A, Stendahl J. 2009. Organic Carbon Stocks in Swedish Podzol Soils in Relation to Soil Hydrology and Other Site Characteristics. Silva Fennica. 43:209-222.

Örlander G, Gemmel P, Wilhelmsson C. 1991. Effects of scarification, planting depth and planting spot on seedling establishment in a low humidity area in southern Sweden. Institutionen för skogsskötsel, SLU. Rapport nr 33.

Rantala J, Harstela P, Saarinen V-M, Tervo L. 2009. A techno-economic evaluation of Bracke and M-Planter tree planting devices. Silva Fennica. 43:659-667.

Rantala J, Laine T. 2010. Productivity of the M-Planter Tree-Planting Device in Practice. Silva Fennica. 44:859-869.

Rummukainen A, Kautto K, Tervo L. 2003. Estimating the Theoretical Development Potential of a Boom-tip Forest Planting Machine. Baltic Forestry. 9:81-86.

Saarinen V-M, Hyyti H, Laine T, Strandström M. 2013. Kohti jatkuvatoimista koneistutusta [Towards continuously operating planting machines]. Metsätehon raportti 227.

Saarinen VM. 2006. The effects of slash and stump removal on productivity and quality of forest regeneration operations - preliminary results. Biomass \& Bioenergy. 30:349-356.

Saksa T, Heiskanen J, Miina J, Tuomola J, Kolstrom T. 2005. Multilevel modelling of height growth in young Norway spruce plantations in southern Finland. Silva Fennica. 39:143153.

Saksa T, Tervo L, Kautto K. 2002. Forest regeneration and slash. Metla [Finnish Forest Research Institute]. Research Papers 851. ISBN 951-40-1831-1. 
Salminen H, Varmola M. 1993. Influence of initial spacing and planting design on the development of young Scots pine (Pinus sylvestris L.) stands. Silva Fennica. 27:21-28.

Sängstuvall L, Bergström D, Lämås T, Nordfjell T. 2012. Simulation of harvester productivity in selective and boom-corridor thinning of young forests. Scandinavian Journal of Forest Research. 27:56-73.

SCA. 2013. Så här ska du plantera [This is how you should plant]. SCA Skog.

Sjunnesson S. 1970. Simulation as a tool for analysis of man/machine systems for thinning. Institutionen för skogsteknik, Skogshögskolan. Rapporter och Uppsatser 42.

Skogsstyrelsen. 2014. Skogsvårdslagstiftningen [The Forestry Act]. Swedish Forest Agency.

Sønsteby F, Kohmann K. 2003. Forsøk med maskinell planting på Østlandet [Mechanized Planting Trials in Østlandet]. Norsk Institutt for Skogforskning. Oppdragsrapport. 3/03.

St-Amour M. 2009. Reforestation trials with the Bräcke P11.a planter. FPInnovations-FERIC. Advantage Report Vol. 11, No. 19.

Ståndortskarteringen [Internet]. 2014. Uppsala: Department of Soil and Environment, SLU; [cited 2014-04-04]. Available from: http://www-markinfo.slu.se/.

Stendahl J, Lundin L, Nilsson T. 2009. The stone and boulder content of Swedish forest soils. Catena. 77:285-291.

Stiell WM. 1982. Growth of clumped vs. equally spaced trees. Forestry Chronicle. 58:23-25.

Sundblad L-G. 2009. Grävmaskinburet aggregat klarar både inversmarkberedning och högläggning [A new unit available for mechanized inverting]. Skogforsk. Resultat nr 11.

Sutton RF. 1993. Mounding site preparation: A review of European and North American experience. New Forests. 7:151-192.

Talbot B, Suadicani K. 2005. Analysis of two simulated in-field chipping and extraction systems in spruce thinnings. Biosystems Engineering. 91:283-292. 